\title{
RELEVANSI DAN APLIKASI ALIRAN EKONOMI KELEMBAGAAN
}

\author{
Purbayu Budi Santosa \\ Fakultas Ekonomi Universitas Diponegoro Semarang, Jawa Tengah \\ E-mail: purbayubudisantosa@yahoo.co.id
}

\begin{abstract}
School of institutional economics emerged as rampant reaction of education and usage of neoclassic economics in research and policy application at most developed and developing countries. The school in developed countries gets many criticisms, also in developing countries that having difference in condition of economics area, social, politics, law, and culture. Usage of qualitative and quantitative research method can be utilized because of approach of the method which holistic. Usage of institutional economics school in education, research, and policymaking, appropriate in Indonesia with economics problem complexity.
\end{abstract}

Key words: neoclassic economic, institutional economic, research method

\section{PENDAHULUAN}

Bagi mahasiswa ekonomi, staf pengajar bahkan para pengguna jasa ekonomi (termasuk manajemen dan akuntansi) merasa kurang puas seandainya dalam penggunaan alat analisisnya tidak menggunakan analisis kuantitatif. Hal ini tidak sepenuhnya salah, akan tetapi pemutlakan terhadap alat analisis kuantitatif, sebenarnya membuat langkah keliru, karena alat analisis lainnya juga tersedia dan mungkin mempunyai ketepatan yang bisa lebih tinggi.

Kekeliruan yang mendasar terhadap pemakaian alat analisis kuantitatif, bermula dari merajalelanya aliran (madzab) Neoklasik, yang banyak dipakai negara maju, sepertinya negara Amerika Serikat dan Eropa. Keberhasilan negara maju dengan tingginya pertumbuhan ekonomi dan pendapatan per kapita, banyak menginspirasi negara terbelakang (sedang berkembang) untuk meniru keberhasilan negara maju tersebut.

Pendidikan ekonomi di negara sedang berkembang berkiblat kepada negara maju dengan aliran Neoklasiknya. Aliran ini merupakan perkembangan lebih lanjut dari aliran Klasik yang dirintis oleh Adam Smith, dimana campur tangan negara boleh dikatakan tidak ada dalam urusan ekonomi, ditambah dengan penggunaan matematika dalam menganalisis ekonomi.

Menurut Mubyarto (2002) ilmu ekonomi yang diajarkan dan diterapkan di seluruh dunia sejak Perang Dunia II, dirintis awal oleh buku Paul Samuelson yang berjudul Economics an Introductory Analysis (MIT, 1946). Inti ajaran yang dikemukakan oleh Samuelson dikenal sebagai teori ekonomi Neoklasik. Isi ajaran ekonomi Neoklasik merupakan sintesis antara teori ekonomi pasar persaingan bebas Klasik (homo economicus dan invisible hand Adam Smith), 
dan ajaran marginal utility dan keseimbangan umum Neoklasik. Penekanan ajaran ekonomi Neoklasik adalah bahwa mekanisme pasar persaingan bebas, dengan asumsi-asumsi tertentu, selalu menuju keseimbangan dan efisiensi optimal yang baik bagi semua orang. Artinya jika pasar dibiarkan bebas, tidak diganggu oleh aturan-aturan pemerintah yang bertujuan baik sekalipun, masyarakat secara keseluruhan akan mencapai kesejahteraan bersama yang optimal (Pareto Optimal).

Samuelson mampu menumbuhkan inspirasi ilmu ekonomi seperti berfungsi sebagai agama, dimana kutub akhir dari kegiatan ekonomi adalah efisiensi pasar. Mencuatnya negara maju karena penerapan ajaran Samuelson, maka bagi masyarakat umum timbul keyakinan "Tuhan berpihak kepada kami" dan pasar juga telah "diberkati" oleh Tuhan. Pada akhirnya dalam setiap kegiatan, menurutnya yang efisien adalah yang terbaik, sedangkan yang tidak efisien harus disingkirkan karena tidak baik.

Kritik terhadap keberadaan aliran Neoklasik telah banyak dikemukakan oleh para ahli baik ahli ekonomi maupun ahli lainnya. Uraian berikut berupa beberapa kritik yang telah diajukan terhadap pemakaian aliran Neoklasik yang terlalu dominan di negara berkembang khususnya, termasuk dari aliran Kelembagaan. Dari kritik yang diajukan kepada aliran Neoklasik, menggambarkan relevansi penggunaan aliran Kelembagaan dalam kancah penggunaan teori ekonomi. Selanjutnya dikemukakan pemahaman terhadap aliran Kelembagaan, yang ternyata nantinya dapat dilihat telah mengalami perkembangan yang cukup jauh. Kemudian akan dikemukakan bagaimana relevansinya pemakaian aliran Kelembagaan bagi kasus-kasus ekonomi.

\section{PEMBAHASAN}

\section{Kritik terhadap Neoklasik}

Sebenarnya peneliti Belanda yang bernama J.H. Boeke dalam disertasinya pada tahun 1910 , telah menyatakan terdapatnya dualisme sosial-ekonomi pada masyarakat di Hindia Belanda (Indonesia). Pada satu sisi pada masyarakat yang maju (perkebunan yang dikuasai oleh Belanda) berlaku prinsip ekonomi yang berujung pada pengejaran keuntungan, akan tetapi pada masyarakat kebanyakan (petani) masih berpola subsisten dimana prinsip ekonomi boleh dikatakan tidak berlaku. Pada akhirnya, menurut Boeke pada negara-negara sedang berkembang memang perlu dikembangkan teori ekonomi tersendiri, yang berlainan dengan yang berlaku di negara maju (Barat).

Gunnar Myrdal yang dikenal sebagai salah satu ekonom aliran Kelembagaan dan memperoleh hadiah Nobel Ekonomi pada tahun 1974 menyatakan teori ekonomi yang sekarang diajarkan dan diaplikasikan di seluruh dunia adalah berbasis kepada aliran Neoklasik yang cocok untuk negara maju. Menurutnya teori ekonomi tersebut tidak dikembangkan untuk menganalisis masalahmasalah ekonomi negara-negara terbelakang (sedang berkembang), oleh karenanya bagi negara sedang berkembang diperlukan teori yang lain dari negara maju karena perbedaan masalah sosial, ekonomi, politik, hukum, dan budaya.

Pada tahun 1976 telah terbit buku berjudul Economics in the Future yang sebenarnya di dalamnya berisi ketidakpuasan terhadap ajaran ekonomi Neoklasik. Jan Tinbergen dan Gunnar Myrdal sebagai dua contoh penulis kenamaan di buku tersebut mengusulkan di masa mendatang hendaknya 
dapat dikembangkan ilmu ekonomi yang induktif-empirik dan memperhatikan masalah kelembagaan (institutional).

Omerod (1994) menulis buku tentang matinya ilmu ekonomi (the death of economics). Yang dimaksud ilmu ekonomi yang mati adalah aliran Neoklasik, dimana dalam realitanya aliran ini tidak cocok karena banyak menyesatkan dan menyusahkan rakyat banyak. Campur tangan negara dengan kebijakan fiskal dan moneternya tetap diperlukan agar perekonomian suatu negara dapat berkembang dengan kesejahteraan yang relatif merata.

Stiglitz (2002) dan juga Perkins (2005) menyatakan akan adanya bahaya dari globalisasi, yang tidak lain adalah penggunaan teori ekonomi Neoklasik dan diperkuat paham Neoliberalisme. Menurutnya, resepresep yang dipakai oleh IMF dan Bank Dunia semuanya pro pasar yang tercermin pada tujuan terciptanya perdagangan bebas dan globalisasi, hanya menguntungkan sekelompok kecil negara maju dan banyak merugikan negara berkembang. Sebagai contoh, bagaimana pernyataan Stiglitz (2002:20) yang mengecam kebijakan yang diambil oleh lembaga internasional, yang banyak merugikan kaum kecil dan negara sedang berkembang.

For the peasants in developing countries who toil to pay off their countries'IMF debts or the businessmen who suffer from higher value-added taxes upon the insistence of the IMF, the current system run by the IMF is one of taxation without representation. Disillusion with the international system of globalization under the aegis of the IMF grows as the poor in Indonesia, Morocco, or Papua New Guinea have fuel and food subsidies cut, as those in Thailand see AIDS increase as a result of IMF-forced cutbacks in health expenditures, and as families in many developing countries, having to pay for their children's education under so-called cost recovery programs, make painful choice not to send their daughters to school.

Mubyarto (2002) menyatakan ketika terjadi Polemik Ekonomi Pancasila, muncul kesan adanya "kubu UI" dan "kubu UGM", yang pertama dianggap pro-pertumbuhan sedangkan yang kedua pro-pemerataan. Selanjutnya saat terjadi reformasi politik ekonomi tahun 1998, Warta Ekonomi (November 1998) membuat Cover Story "Ekonomi Rakyat Menggeser Berkeley Mafia". Adi Sasono yang ditunjuk menjadi Menkop \& UKM oleh Presiden Habibie memimpin barisan "pembela ekonomi rakyat", sedangkan sejumlah ekonom muda UI (Faisal Basri dan Chatib Basri) menganggap sepi ekonomi rakyat. Emil Salim menolak disalahkan telah memihak konglomerat. "Dari semula prioritas kami adalah pembangunan rakyat kecil dan (karena) sebagian rakyat tinggal di pedesaan, maka prioritas pembangunan harus pertanian”. Menurut Emil Salim, ekonomi Indonesia memang mulai melenceng antara 1998-1993 dan sejak 1993 ekonom satu per satu mulai digusur oleh non ekonom.

Swasono (2002) ketika memberikan ceramah di depan Ikatan Alumni Universitas Diponegoro memberikan kritik ilmu ekonomi yang diajarkan di fakultas-fakultas ekonomi oleh karena masih menganut faham kompetitivisme belaka. Dengan demikian, banyak mengabaikan faham kooperativisme, sementara ilmu ekonomi yang diajarkan itu pun bersifat neo-klasikal (free competition-based economy) berdasarkan inisiatif dan kebebasan individu (liberalism). Dari sinilah sistem 
ekonomi kapitalis mendapat tempat dan pembenaran dengan mudahnya di ruangruang kelas. Kepentingan pribadi mencapai equilibrium-nya dalam wujud tercapainya kepuasan maksimal dan laba maksimal atau pun biaya minimal dan kerugian minimal. Inilah arti efisiensi ekonomi, yang berdasarkan paham bersaing dan persaingan, sehingga siapa yang tidak efisien harus kalah dan tersingkir, dilanjutkan dengan abstraksi tentang bakal dicapainya resource allocation yang paling efisien. Maka lahirlah dari paham ini adagium bebas -keluar dan bebas-masuk (free entry and free exit, bebas hidup dan bebas-gulung tikar).

Arief (2006) menyatakan pada prinsipnya perekonomian pada jaman penjajahan Belanda dan sekarang di jaman kemerdekaan tidak jauh berbeda, yaitu dipakainya faham individualistis, yang dalam hubungan ekonomi terlihat dalam tingkah laku hubungan kapitalis yang hanya mementingkan diri sendiri tanpa peduli kepentingan masyarakat. Sekarang ini, modal asing yang masuk justru menimbulkan transfer keluar yang lebih banyak daripada yang masuk ke Indonesia, pembiayaan dari luar negeri telah menjadi substitusi dan bukannya sebagai tambahan terhadap tabungan dalam negeri, dan industri-industri yang praktis tergantung seluruhnya pada impor dan yang semua industri ini berjalan di atas landasan produksi yang polanya sama dengan yang ada pada jaman kolonial Belanda.

Keen (2001) menyatakan kritiknya atas keberadaan teori ekonomi Neoklasik dan diperlukannya alternatif ajaran lainnya. Alternatif-alternatif yang dikemukakan meliputi:
1. Austrian Economics, yang menerima banyak ajaran ekonomi Neoklasik kecuali konsep keseimbangan.

2. Post Keynesian Economics, yang sangat kritis terhadap ajaran Neoklasik dan menekankan pada pentingnya ketidakpastian.

3. Sraffian Economics, mendasarkan pada konsep produksi komoditas dalam artian komoditas (sektor riil) menjadi icon analisis

4. Complexity Theory, yang menerapkan konsep dinamika non linier dan teori kekacauan terhadap isu-isu ekonomi

5. Evolutionary Economics, yang memperlakukan perekonomian sebagai sistem evolusi mirip ajarannya Darwin.

Dari kelima alternatif yang dikemukakan untuk melengkapi ajaran Neoklasik tersebut, teori ekonomi evolusioner mencakup teori ekonomis yang dikemukakan oleh aliran Kelembagaan. Berdasarkan kritik-kritik yang dikemukakan kepada aliran Neoklasik tersebut, maka menjadikan relevan pemakaian teori ekonomi yang dikemukakan oleh aliran Kelembagaan. Bagaimana sebenarnya perkembangan para tokoh aliran Kelembagaan, dapat dikemukakan di bawah ini.

\section{Aliran Kelembagaan}

Keberadaan aliran Ekonomi Kelembagaan (Institutional Economics) merupakan reaksi dari rasa ketidakpuasan terhadap aliran Neoklasik, yang sebenarnya merupakan kelanjutan dari aliran ekonomi Klasik. Menurut Hasibuan (2003) inti pokok aliran ekonomi Kelembagaan adalah melihat ilmu ekonomi dengan satu kesatuan ilmu sosial, seperti psikologi, sosiologi, politik, 
antropologi, sejarah, dan hukum. Mereka merangkum hal tersebut dalam analisis ekonomi, namun demikian di antara mereka masih mempunyai ragam dan variasi pandangan. Pada garis besarnya mereka menentang pasar bebas atau persaingan bebas dengan semboyan laissez-faire dan motif laba maksimal.

Landreth dan Colander (1994) membagi para tokoh ekonomi Aliran Kelembagaan dalam tiga golongan, yaitu tradisional, quasi dan neo. Yustika (2006) membagi aliran kelembagaan kedalam ilmu ekonomi Kelembagaan lama ('old' institutional economics) dan ilmu ekonomi Kelembagaan baru ('new' institutional economics). Mengkombinasikan dari kedua pandangan tersebut, maka pertama akan dikemukakan aliran ekonomi Kelembagaan lama, kedua quasi dan yang ketiga aliran ekonomi Kelembagan baru. Seperti halnya para pemikir tersebut, pembagian tersebut sifatnya relatif dalam artinya yang dikemukakan kemudian bukan berarti paling baik dan yang lama (tradisional) harus ditinggalkan, akan tetapi hanya dalam hal kesamaan fokus dan isu-isu pemikiran.

\section{Aliran Kelembagaan Lama}

Para pakar setuju bapak ekonomi Kelembagaan adalah Thorstein Bunde Veblen (18571929). Veblen putra migran Norwegia yang menjadi petani di pedesaaan Wisconsin. Pada usia 17 tahun orang tuanya memasukkan Veblen ke Carleton College Academy, karena orang tuanya punya cita-cita puteranya menjadi seorang pendeta. Tetapi nasib menentukan lain, ia memperoleh gelar Doktor Ekonomi dari Yale University pada tahun 1884 dengan nilai A.
Kritik Veblen sangat tajam terhadap ilmu ekonomi ortodoks, dimana pengertian ekonomi ortodoks adalah pemikiranpemikiran ekonomi yang menggunakan dan melanjutkan ekonomi Klasik, seperti persaingan bebas, persaingan sempurna, manusia adalah rasional, motivasi memaksimalkan keuntungan (kepuasan) dan meminimasi pengorbanan ekonomi. Sebaliknya, ekonomi heterodoks melihat perilaku variabel ekonomi dalam lingkungan yang lebih luas, seperti penjelasan-penjelasan yang diberikan aliran sejarah di Jerman dan begitu pula aliran ekonomi kelembagaan yang muncul di Amerika Serikat (Landreth dan Colander, 1994; Brue, 2000; dan Hasibuan, 2003).

Menurut Veblen teori ekonomi ortodoks merupakan teori teologi, oleh karena akhir cerita telah ditentukan dari awal. Misalnya, keseimbangan jangka panjang itu tidak pernah dibuktikan, tetapi telah ditentukan walaupun ceritanya belum dimulai. Ilmu ekonomi menurutnya bukan hanya mempelajari tingkat harga, alokasi sumbersumber tetapi justru mempelajari faktorfaktor yang dianggap tetap (given).

Pada tahun 1899 terbit buku yang berjudul the Theory of Leisure Class. Teori ini menceritakan perilaku kelas orang-orang kaya, dimana mereka berlomba-lomba mengumpulkan kekayaan sebagai motif kekuatan. Benda-benda yang dikumpulkan merupakan gambaran conspicuous consumption (konsumsi mewah), seperti mobil model mutakhir, rumah mewah, pakaian yang eksklusif dan barang-barang yang mahal lainnya yang kesemuanya sebagai cermin kemewahan dan kebanggaan sosial. Jadi menurut Veblen, kelas santai (leisure class) adalah kelasnya orang-orang yang kaya, yang menurutnya sebenarnya mempunyai keseng- 
gangan waktu yang banyak (conspicuous leisure) suka konsumsi mewah dan boros, suka pamer, sehingga sebenarnya perilakunya dapat mubazir (conspicuous waste) dan dapat menjurus kepada keserakahan materi (pecuaniary emulation).

Buku yang lain darinya adalah the Theory of Business Enterprise yang terbit pada tahun 1904. Pengusaha, dalam pandangan Veblen bukanlah penggerak ekonomi, akan tetapi dinilai sebagai penyabot. Masyarakat industri dikurung oleh mesin, dan manusia diatur secara mekanistik. Manusia bekerja disesuaikan dengan mesin, peraturan mesin, dan disiplin mesin. Proses produksi tergantung pada mesin dan fungsi terpenting untuk operatornya tergantung kepada teknisi, sedangkan usahawan menjadi penumpuk kekayaaan, harga pun menjadi mahal. Kaum pengusaha membentuk super struktur tersendiri, mereka lebih sibuk mengurus perkreditan, keuangan dan perdagangan dan mereka menjadi orangorang kaya karena merampok, yang Veblen sebut robber-barons.

Tokoh berikut yang perlu dikemukakan adalah Wesley Clair Mitchell (1874-1948). Michell merupakan salah satu ahli ekonomi kenamaan di Amerika Serikat dan merupakan pendiri National Bureau of Economic Research. Mengumpulkan data makro menurutnya adalah lebih penting daripada memberi sumbangan kepada teori ekonomi murni. Kumpulan-kumpulan tulisannya dihimpun dalam buku Lecture Notes on Types Economic Theory.

Ketika belajar di Universitas Chicago, Mitchell mempelajari sejarah pemikiran ekonomi dari Quesnay sampai Marshall. Menurutnya, logika-logika yang deduktif itu hampir tidak berguna dalam mempelajari ekonomi. Meskipun demikian, ia mulai melirik dan tertarik kepada pemikiran-pemikiran yang dikemukakan gurunya yaitu Veblen. Michell selanjutnya berpendapat bahwa kelemahan metodologis yang ditemukakan pada Veblen sama dengan yang ditemukannya pada aliran ekonomi ortodoks. Hal ini disebabkan keduanya gagal untuk menguji asumsi-asumsi mana yang dapat membawa hasil yang memuaskan.

Penelitian Mitchell yang tanpa terikat kepada teori-teori tertentu, dapat disimak pada tulisannya rentang siklus ekonomi (business-cycles). Pendekatannya sangat cermat dengan membangun dan memberi penjelasan terhadap berbagai rangkaian data dalam uraian waktu dan mulai menyusun langkah-langkah menuju teori yang bersifat sementara.

Pendekatannya cenderung pada evolusioner sebab-musabab yang kumulatif. Menurutnya setiap siklus ekonomi sifatnya unik, maka untuk membentuk model yang sifatnya umum relatif sukar karena setiap siklus mempunyai ciri-ciri persamaan. Persamaan ciri itu timbul karena adanya kekuatankekuatan ekonomi yang muncul dalam berbagai tahap siklus, seperti resesi, pemulihan (recovery), masa makmur (prosperity) dan depresi. Mitchell melihat adanya siklus karena suatu self generating process, yang diperolehnya dari himpunan data empiris. Dengan demikian Mitchell senantiasa dikenal oleh para ahli ekonomi dan mahasiswa ekonomi, oleh karena Mitchell berjasa besar dalam pengembangan penelitian ekonomi di Amerika Serikat dan pendiri National Bureau Economic Research.

Ajaran ekonomi kelembagaan dapat berkembang di Universitas Wisconsin berkat jasa John R. Commons (1826-1945). Beliau 
berusaha mencoba melakukan perubahan sosial, penyempurnaan struktur dan fungsi pendidikan di kampus tersebut dan banyak memberikan sumbangan dalam ekonomi perburuhan. Cita-citanya banyak mendapat dukungan dari orang-orang penting seperti gubernur negara bagian tersebut maupun politisi, sehingga banyak undang-undang yang disusun dalam rangka melakukan perubahan sosial dan perburuhan.

Commons seperti halnya para penganut aliran ekonomi kelembagaan, banyak melakukan kritik terhadap aliran ekonomi ortodoks, seperti lingkungan ekonomi yang terlalu sempit, statik, dan dia berusaha memasukkan segi-segi kejiwaaan, sejarah, hukum, sosial, dan politik dalam pembahasannya. Sebagai misal, teori harga dalam ekonomi ortodoks hanya berlaku dalam kondisi-kondisi tertentu. Di dalam pasar, menurut ekonomi ortodoks hanya terjadi pertukaran yang mempunyai tiga fungsi yaitu transaksi pengalihan hak milik kekayaan, transaksi kepemimpinan, dan transaksi distribusi. Dalam transaksi tersebut sebenarnya melibatkan aspek-aspek kebiasaan, adat, hukum, dan kejiwaan. Begitu juga, dalam kegiatan ekonomi bukan hanya individu, tetapi juga kelompok dan anggota-anggota kelompok yang diatur oleh aturan permainan. Aturan-aturan itu merupakan ketentuan yang harus ditaati bersama, yang bertujuan untuk kemajuan individu, membebaskan individu dari tekanan dan diskriminasi. Keberadaan persaingan bebas beliau kecam, tetapi yang diperlukan campur tangan pemerintah untuk melakukan regulasi.

Salah seorang tokoh ekonomi kelembagaan dari Inggris yang penting adalah John A. Hobson (1858-1940). Menurutnya, ada tiga kelemahan teori ekonomi ortodoks, yaitu tidak dapat menyelesaikan masalah fullemployment, distribusi pendapatan yang senjang dan pasar bukan ukuran terbaik untuk menentukan ongkos sosial. Beliau tidak setuju adanya pembagian ekonomi positif dan normatif, karena keduanya tetap memerlukan adanya unsur etika.

Selanjutnya Hobson berpendapat tentang timbulnya imperialisme disebabkan karena terjadinya konsumsi yang kurang dan kelebihan tabungan di dalam negeri, maka diperlukan penanaman modal ke daerahdaerah jajahan. Menurutnya juga, pengeluaran pemerintah dan pajak dapat mendorong ekonomi ke arah full-employment dan peningkatan pendapatan pekerja dan produktivitas. Dengan semakin meratanya pembagian pendapatan akan mendorong peningkatan produktivitas dan konsumsi, yang berarti bisa terhindar dari bahaya adanya resesi.

\section{Aliran Quasi Kelembagaan}

Para tokoh yang masuk ke dalam aliran ini adalah mereka yang terpengaruh oleh pemikiran Veblen dan kawan-kawannya, akan tetapi sifatnya terlalu individualis dan iconoclastic dan corak pemikirannya berbeda dengan aliran kelembagaan yang baru. Para tokoh aliran ini antara lain Joseph Schumpeter, Gunnar Myrdal, dan John Kenneth Galbraith.

Schumpeter lahir di Austria pada tahun 1883 dan meninggal pada tahun 1950 di Amerika Serikat. Gelar hukum diraihnya di Universitas Wina pada tahun 1906, pernah menjadi menteri keuangan di Austria dan kemudian menjadi guru besar pada Universitas Bonn, walaupun kemudian pindah ke Universitas Harvard. 
Buku-buku yang pernah ditulisnya, diantaranya Theory of Economic Development (1911), Business Cycles (1939) dan buku terakhir ditulis bersama isterinya Elizabeth B. Schumpeter berjudul Capitalism, Socialism and Democracy.

Pemikiran Schumpeter bertumpu kepada ekonomi jangka panjang, yang terlihat dalam analisisnya baik mengenai terjadinya inovasi komoditi baru, maupun dalam menjelaskan terjadinya siklus ekonomi. Keseimbangan ekonomi yang statis dan stasioner seperti konsep kaum ortodoks mengalami gangguan dengan adanya inovasi. Meskipun demikian, gangguan tersebut dalam rangka berusaha mencari keseimbangan yang baru. Inovasi bisa tidak berlanjut kalau kaum wiraswasta (kapten industri) telah terjebak dalam persoalan-persoalan yang sifatnya rutin.

Meskipun Schumpeter kadang-kadang masih menggunakan beberapa asumsi ekonomi ortodoks, akan tetapi juga memasukkan aspek dinamik dengan mengkaji terjadinya fluktuasi ekonomi dimana terjadi resesi, depresi, penyembuhan (recovery) dan berada puncak (boom). Invensi dan inovasi merupakan kreativitas dalam pembangunan, tetapi dapat terkandung sifat destruktif, seperti katanya: Today's innovation replaces yesterday and tomorrow is itself replaced. Jadi dengan inovasi tersebut keseimbangan yang statis terganggu, oleh karena arus uang meningkat dan tingkat harga juga meningkat. Sebaliknya terjadi pula kontraksi bilamana barang-barang baru itu melimpah di pasar, sedangkan kredit harus dibayar, sehingga tahap resesi akan terjadi seperti telah dikemukakan oleh Micthell. Meskipun begitu, keseimbangan baru dapat terjadi lagi tetapi tidak dalam kondisi semula. Posisi keseimbangan baru berada dalam titik keadaan yang lebih besar karena telah terjadi pertumbuhan ekonomi.

Gunnar Myrdal lahir di Swedia pada tahun 1898 dan wafat pada tahun 1987. Mula-mula beliau tertarik dengan pengkajian ideologi dan teori ekonomi seperti yang pandangannya ditemukan dalam buku karyanya berjudul The Political Element in the Development of Economic Theory (1930). Selanjutnya pada tahun 1944 terbit pula bukunya berjudul An American Dilemma, the Negro Problem and Modern Democracy. Uraian-uraian dalam buku ini membawanya ke pembahasan dalam lapangan sosiologi, problematika kependudukan, politik, dan hak-hak warga negara khususnya yang berkaitan dengan keberadaan kaum kulit hitam di Amerika Serikat.

Perhatian Myrdal lebih tertarik kepada keterbelakangan pada berbagai negara sedang berkembang yang problematikanya berbeda dengan negara maju, seperti tampak dalam bukunya An International Economy (1956), Rich Lands and Poor (1957), Beyond the Welfare State (1960), Challenge to Affluence (1962), Asian Drama (1968), dan The Challenge of World Poverty (1970). Menurutnya, keberadaan teori ekonomi dari kaum ortodoks tidak banyak menolong keterbelakangan negara sedang berkembang, sehingga diperlukan teori yang khas dan cocok bagi negara sedang berkembang.

Myrdal berpendapat bagi negara sedang berkembang supaya bisa maju diperlukan perencanaan pembangunan, yang meliputi segala aspek yaitu aspek ekonomi, pendidikan, kesehatan, kependudukan, maupun sektor lainnya. Alat analisis yang dapat dipergunakan dipengaruhi pemikiran Mitchell, yaitu sebab-musabab yang bersifat kumulatif. Jadi menurutnya, kekuatan- 
kekuatan politik, ekonomi, sosial, dan kejiwaan dapat berhimpun menjadi sebab kejadian yang merugikan atau yang menguntungkan pembangunan.

John Kenneth Galbraith lahir pada tahun 1908 di Kanada, ia merupakan alumni dari Berkeley dalam bidang ekonomi pertanian dan menjadi guru besar pada Universitas Harvard Amerika Serikat. Beliau pernah menjadi penasehat partai demokrat, editor majalah terkenal Fortune dan duta besar Amerika Serikat di India. Bukunya yang terkenal di antaranya American Capitalism (1952), The Affluence Society (1958), dan The New Industrial State (1967).

Galbraith menjelaskan perkembangan ekonomi kapitalis di Amerika Serikat yang tidak sesuai dengan perkiraan (prediksi) yang dikemukakan kaum ekonomi ortodoks. Asumsi-asumsi yang dikemukakan oleh teori ekonomi ortodoks dalam kenyataannya melenceng jauh sekali. Keberadaan pasar persaingan sempurna tidak ada, bahkan pasar telah dikuasai oleh perusahaan-perusahaan besar. Perusahaan-perusahaan ini demikian besar kekuasaannya sehingga selera konsumen bisa diaturnya, sehingga memunculkan istilah dependent-effect.

Pada perusahaan yang demikian besar tersebut, pemilik modal telah terpisah dengan para manajer profesional dan para manajer ini telah menjadi technostructure masyarakat. Konsumsi masyarakat telah menjadi demikian tinggi, tetapi sebaliknya terjadi pencemaran lingkungan, dan kualitas barangbarang swasta tidak dapat diimbangi oleh barang-barang dan jasa publik. Selanjutnya, kekuatan-kekuatan perusahaan besar dikontrol oleh kekuatan pengimbang seperti kekuatan buruh, pemerintah dan lembagalembaga konsumen. Namun demikian, untuk menjamin keberlanjutan perusahaan-perusahaan ini, maka pemerintah hendaknya berfungsi untuk menstabilkan perkembangan ekonomi.

\section{Aliran Kelembagaan Baru}

Aliran Ekonomi Kelembagaan Baru (New Intstitutional Economics disingkat NIE) dimulai pada tahun-tahun 1930-an dengan ide dari penulis yang berbeda-beda. Menurut Yustika (2006), pada tahun-tahun terakhir ini terjadi kesamaan ide yang mereka usung itu kemudian dipertimbangkan menjadi satu payung yang bernama NIE. Secara garis besar, NIE sendiri merupakan upaya 'perlawanan' terhadap dan sekaligus pengembangan ide ekonomi Neoklasik, meskipun tetap saja dapat terpengaruh oleh ideologi dan politik yang pada pada masing-masing para pemikir.

Ronald Coase yang memperoleh hadiah Nobel Ekonomi pada tahun 1991 dan merupakan salah satu peletak dasar NIE, mengembangkan gagasannya tentang organisasi ekonomi untuk mengimbangi gagasan intelektual kebijakan kompetisi dan regulasi industri Amerika Serikat pada tahun 1960-an, yang menganggap semua itu dapat dicapai oleh kebebasan ekonomi dan kewirausahaan. Meskipun begitu, NIE bisa begitu menarik bagi sebagian pemikir kiri (left-wing thinkers), yaitu mereka yang merasa NIE dapat menyediakan dasar intelektual (teoritis) untuk melunturkan dominasi aliran Neoklasik atau aliran sejenisnya yang bertumpu kepada keberadaan pasar bebas.

NIE dengan demikian menempatkan dirinya sebagai pembangun teori kelembagaan nonpasar dengan fondasi teori ekonomi Neoklasik. Seperti yang diungkapkan oleh salah satu tokoh NIE Douglass C. North, 
bahwa NIE masih menggunakan dan menerima asumsi dasar dari ekonomi Neoklasik mengenai kelangkaan dan kompetisi akan tetapi meninggalkan asumsi rasionalitas instrumental (instrumental rationality). Oleh karena ekonomi Neoklasik memakai asumsi tersebut menyebabkan menjadi teori yang bebas kelembagaan (institutional-free theory).

NIE selanjutnya memperdalam kajiannya tentang kelembagaan nonpasar, seperti hak kepemilikan, kontrak, partai revolusioner, dan sebagainya. Hal ini dilakukan karena sering terjadinya masalah kegagalan pasar (market failure). Kegagalan pasar muncul dalam rupa terjadinya asimetris informasi, eksternalitas produksi (production externality) dan adanya kenyataan keberadaan barang-barang publik (public goods). Akibat kealpaan teori ekonomi Neoklasik terhadap adanya kegagalan pasar, maka dilupakan pula adanya kenyataan pentingnya biaya-biaya transaksi (transaction cost). Di samping itu NIE menambah bahasannya tentang terjadinya kegagalan kelembagaan (institutional failure) sebagai penyebab terjadinya keterbelakangan pada banyak negara.

Kegagalan kelembagaan tersebut menurut Bardhan merujuk kepada struktur kontrak dan hukum, serta regulasi dari penegakan pihak ketiga (rules of third party enforcement) yang lemah, padahal semua itu harus diperkuat untuk menjalankan transaksi pasar (Yustika, 2006).

Karakteristik dari para ahli NIE adalah selalu mencoba menjelaskan pentingnya kelembagaan (emergency of institutions), seperti perusahaan atau negara, sebagai model referensi terhadap perilaku individu yang rasional untuk mencegah kemungkinan yang tidak diinginkan dalam interaksi manu- sia. Faktor penjelasnya adalah dari individu ke kelembagaan (from individuals of institutions), dengan menganggap individu sebagai apa adanya (given). Pendekatan ini kemudian dideskripsikan sebagai methodological individualism.

NIE membangun gagasannya bahwa kelembagaan dan organisasi berupaya supaya mencapai tingkat efisiensi dan meminimalisasikan biaya menyeluruh. Dalam konsep biaya menyeluruh, tidak hanya berupa ongkos produksi seperti konsepsinya ekonomi Neoklasik, akan tetapi juga biaya transaksi. Keadaan pasar yang kompetitif bisa sebagai seleksi alamiah, dimana hanya perusahaan yang efisien yang diuntungkan, akan tetapi perlu pula dicatat bahwa lingkungan dunia nyata bisa tidak pasti dan ajeg sehingga segala kemungkinan bisa saja terjadi.

NIE di sisi lainnya beroperasi pada dua level, yaitu lingkungan makro yang disebut dengan lingkungan kelembagaan (institutional environment) dan lingkungan mikro yang disebut dengan kesepakatan kelembagaan (institutional arrangement). Lingkungan kelembagaan merupakan seperangkat struktur aturan politik, sosial dan legal yang memantapkan kegiatan produksi, pertukaran, dan distribusi. Lingkungan kebijakan ekonomi sebagai lingkungan makro meliputi antara lain aturan mengenai tata cara pemilihan, hak kepemilikan, dan hak-hak di dalam kontrak.

Kesepakatan kelembagaan merupakan kesepakatan antara unit ekonomi untuk mengelola dan mencari jalan agar hubungan antar unit tersebut dapat berlangsung, baik lewat cara kerjasama maupun kompetisi. Dengan demikian sebenarnya kesepakatan kelembagaan berhubungan dengan tata kelola kelembagaan (institutions of governance). 
Sebuah kesepakatan kepemilikan merupakan kesepakatan kelembagaan karena di dalamnya mengalokasikan hak-hak kepemilikan kepada individu, kelompok atau pemerintah. Kesepakatan kelembagaan bisa berupa pula cara untuk mengelola transaksi, baik melalui pasar, pasar bayangan (quasi-market) maupun model kontrak yang memakai hierarchy.

NIE secara definitif merupakan studi multidisiplin, dimana ilmu ekonomi berekspansi dengan wilayah ilmu sosial, khususnya hukum, politik dan sosiologi; sehingga memiliki beberapa cabang ilmu. Meskipun masih terjadi diskusi tentang wilayah kajian NIE, namun setidaknya cabang-cabang dari NIE dapat dibagi dalam dua kategori.

Pertama, sejarah ekonomi baru (new economic history) dikembangkan oleh North, Fogel dan Rutherford dan aliran pilihan publik (public choice school), yang dikembangkan oleh Buchanan, Tullock, Olson, dan Bates. Kedua, teori ekonomi biaya transaksi (transaction cost economics) dikembangkan oleh Ronald Coase, Douglass North dan Oliver Wiliamson dan informasi ekonomi (economics information) yang diperkenalkan oleh Akerlof, Stigler dan Stiglitz. Di luar itu masih terdapat beberapa cabang lainnya yang cukup menarik, seperti teori ekonomi sosial baru (new social economics) yang dikembangkan oleh Garry S. Becker, teori tindakan kolektif (collective action theory) yang ditekuni oeh Mancur Olson, serta teori hukum dan ilmu ekonomi (law and economics) yang diminati oleh Posner.

\section{Implikasi}

Berdasarkan uraian yang telah dikemukakan, lahirnya Aliran Ekonomi Kelembagaan merupakan reaksi dari keberadaan aliran ekonomi Neoklasik, yang ternyata banyak kelemahan- nya, akan tetapi banyak menguasai para pemikir ekonomi dan banyak diaplikasikan pada berbagai negara, termasuk negara sedang berkembang. Penerapan aliran ekonomi Neoklasik pada berbagai negara maju tidak luput dari kritik, apalagi bagi negara sedang berkembang yang kondisi fisik maupun lingkungannya jelas berbeda dimana aliran ekonomi Neoklasik itu muncul.

Paarberg (1993, dalam Arifin dan Didik J. Rachbini, 2001) menyatakan ekonomi kelembagaan memakai pendekatan idealistik, satuan observasi transaksi, tujuan individual adalah diri sendiri dan orang lain, hubungan dengan ilmu-ilmu sosial lain adalah hampir semua ilmu sosial, konsep nilai adalah nilai dalam penggunaan, konsep ekonomi dengan pendekatan budaya, falsafah Pasca-Dewey, tingkah laku social behaviorist, postulat ketidakseimbangan, fokus keseluruhan, metode ilmiah kebanyakan normatif, data kebanyakan kualitatif, sistem terbuka, ekonometrika tidak/kadang dipakai, visi ekonomi lebih ke arah dinamis, peranan merekomendasikan pilihan, dan sikap terhadap kegiatan kolektif tidak dapat dihindari.

Aliran ekonomi kelembagaan percaya bahwa kondisi ekonomi akan menentukan bentuk struktur kelembagaan. Aliran ini ini juga mementingkan bekerjanya suatu sistem perekonomian. Transaksi-transaksi ekonomi hanya dapat terjadi karena adanya kelembagaan, sehingga tanpa kelembagaan mustahil akan timbul transaksi ekonomi.

Soegianto dalam pidato pengukuhannya sebagai guru besar pada Fakultas Ekonomi Universitas Diponegoro Semarang (2007) menyatakan pendekatan positivistik yang sebenarnya menjadi ciri ekonomi Neoklasik telah membawa pandangan ilmu ekonomi yang bebas nilai. Demikian pula ideologi 
kebebasan individual dan prinsip maksimisasi utilitas telah melahirkan pragmatisme dan perilaku hedonis. Sterilisasi atas fenomena ekonomi dari konteks sosialnya inilah yang telah menjadi salah satu sumber penyebab utama krisis ekonomi di Indonesia.

Guna mengatasi keadaan perekonomian Indonesia yang carut-marut, menurut Soegianto strategi pembangunan ekonomi di Indonesia harus mengalami pergeseran, dimulai dengan orientasi terhadap peningkatan keadilan dan pemerataan dengan menempatkan penghapusan kemiskinan dan penciptaan lapangan pekerjaan sebagai tujuan utama pembangunan. Menurutnya, penekanan terhadap kelembagaan akan menentukan keberhasilan dalam menyelesaikan masalah-masalah pembangunan (institution matter). Kelembagaan yang dimaksudkan di sini adalah aturan main (rule of the game) yang berlaku di masyarakat, baik formal seperti undang-undang, hukum dan peraturan, maupun nonformal seperti norma-norma yang berlaku, kebiasaan, dan adat istiadat.

Santosa (2006) menyatakan perlunya dilakukan pendekatan terhadap kasus-kasus ekonomi di Indonesia dengan pendekatan ekonomi kelembagaan disebabkan kacaunya data statistik karena praktek korupsi yang menggurita, sumber utamanya pada kasus politik uang pada saat pemilihan para elite di Indonesia. Begitu juga, penelitian maupun kebijakan pembangunan yang dilakukan perlu memperhatikan modal sosial baik yang dipunyai oleh para warga negara maupun pada pemerintahan yang sebenarnya dalam keasliannya sangatlah baik. Santosa (1985) dalam penelitiannya mengamati pengaruh budaya (culture) terhadap pembangunan, khususnya pembangunan desa. Hasil penelitian menunjukkan bahwa gotong royong terpengaruh oleh sistem religi yang dianut dalam masyarakat dan dalam hal ini dengan memakai kriterianya Clifford Geertz, yaitu abangan dan santri. Salah satu temuannya adalah di dalam wilayah pedukuhan tipe abangan, partisipasi masyarakat dalam pembangunan desa bersifat tradisional, misalnya bekerja sama dalam mencari batu dan bekerja sama pula dalam mengerjakan pembangunan jalan. Sedangkan bagi penduduk dengan tipe santri karena terpengaruh tradisi dagang Nabi yang lebih suka secara bersama menyumbangkan uang. Meskipun begitu, kegiatan gotong royong mencerminkan etos subsistensinya Scott, di mana bagi golongan masyarakat dengan status sosial tinggi dapat meninggalkan kerja bakti dan tolong menolong, asal tahu diri. Karena konsep tahu diri berdasarkan kesadaran moral dapat mampat, sehingga berakibat pada munculnya kasus white collar crime.

Chariri (2006) meneliti bagaimana pengaruh budaya terhadap praktik laporan keuangan pada Perusahaan Asuransi di Indonesia. Metode penelitian yang dipakai pada studi kasus etnografik. Hasil penelitian menunjukkan bahwa perusahaan berkomitmen dengan praktik pelaporan keuangan karena pelaporan yang demikian dapat dipergunakan untuk menjaga keabsahan dan harmoni sosial, yang sesuai dengan budaya Jawa yang dipakai oleh manajemen perusahaan tersebut. Para pelaku yang terlibat pada penyusunan praktik laporan keuangan di perusahaan banyak terpengaruh budaya organisasi, yang khas budaya Jawa yaitu menjaga nilai-nilai etika dan transparansi dalam praktek bisnis antara tingkat atasan dan bawahan. Demikian juga budaya tersebut dapat mengatasi pihak luar yang mempermasalahkan praktik laporan keuangan. Studi ini 
menemukan bahwa kekuasaan dan kepemimpinan mempengaruhi praktik laporan keuangan, yang di budaya Jawa dituntun oleh pedoman bijak ing ngarso sung tolodo, ing madyo mangun karso dan tut wuri handayani. Pada akhirnya studi ini menunjukkan bahwa akuntansi adalah ilmu sosial yang tidak bebas nilai, tetapi merupakan realitas yang dibentuk (dikonstruksi) secara sosial.

Jaya (2004) mengadakan kajian teoritis sejauhmana peran Ekonomi Kelembagaan Baru (NIE) dapat diaplikasikan pada kasus otonomi daerah di Indonesia. Dalam mengkaji hal tersebut, bisa diaplikasikan bahwa daerah (negara) merupakan hubungan kontrak antara prinsipal yaitu konstituen dengan agen perwakilan.

Yustika (2005) meneliti bagaimana penerapan ekonomi Kelembagaan pada masalah industri pergulaan di Indonesia. Menurut peneliti tersebut, kemunduran industri gula nasional disebabkan oleh inefisiensi kelembagaan (institutional inefficient), baik pada tingkat kebijakan kelembagaan (institutional environment) maupun kesepakatan kelembagaan (institutional arrangement).

Karseno dan Arti Adjie (2001) telah mengadakan penelitian mengenai kebijakan ekonomi dan pembangunan kelembagaan di Indonesia. Kedua peneliti tersebut menyoroti kelemahan perekonomian Indonesia di masa pemerintahan Orde Baru yang berupa kurangnya pembangunan kapasitas kelembagaan dan sumber daya manusia.

Arifin (2005) mengadakan penelitian mengenai ekonomi kelembagaan pangan di Indonesia. Kerangka dasar yang dipakai adalah historis, hirarki, dan ekspektasi dari kelembagaan pangan. Hasil penelitian menunjukkan pentingnya peran pemerintah pusat dan daerah dalam menjalankan sistem kelembagaan ketahanan pangan. Pentingnya peran lembaga parastatal seperti Bulog menjadi jangkar utama dalam pengadaan pangan dalam negeri serta perbaikan aksesibilitas melalui program beras orang miskin (raskin). Kebijakan yang perlu diambil dalam ekonomi kelembagaan pangan, adalah jangka pendek adalah terciptanya keseimbangan ketahanan pangan, jangka menengah adalah terjadinya cadangan pangan serta usaha diversifikasi usaha dan penganekragaman pangan dan jangka panjang perlu pengembangan kelembagaan ketahanan pangan dengan pembagian yang jelas antara pemerintah dan masyarakat.

\section{PENUTUP}

Keberadaan aliran ekonomi kelembagaan sebagai reaksi dari dominasi aliran ekonomi ortodoks (utama), yang bukan saja di negara maju banyak dikritik, akan tetapi penerapannya di negara sedang berkembang banyak mengalami kemencengan. Munculnya kemiskinan, pengangguran, ketimpangan, keresahan sosial, dan kerusakan lingkungan barangkali bisa dialamatkan kepada penerapan ekonomi Neoklasik, sebagai pendukung paling utama aliran ortodoks. Bahkan dari berbagai keadaan yang terjadi tersebut memunculkan rasa skeptisisme akan keberadaan ilmu ekonomi bahkan ada yang mengatakan ilmu ekonomi telah mati.

Aliran ekonomi kelembagaan yang akan menyoroti masalah ekonomi kaitannya dengan disiplin ilmu-ilmu lainnya, memungkinkan pendekatannya bersifat holistik. Akibatnya bisa dipergunakan analisis kuantitatif maupun kualitatif sesuai dengan kasus-kasus ekonomi yang terjadi. Penggunaan matema- 
tika, statistika, bahkan ekonometrika bisa saja dipakai, meski pemutlakan terhadap alat analisis tersebut harus dihindari. Pendekatan etnografis, grounded research, historis, interdisiplin, multidisiplin, transdisiplin, bahkan jenis metode penelitian kualitatif lainnya sah-sah saja untuk dipakai.

Keadaan ini nampak juga dari aliran Ekonomi Kelembagaan yang sangat beragam dan dengan sejumlah ahli yang mempunyai latarbelakang pendidikan yang berbeda pula. Meskipun aliran Ekonomi Kelembagaan bisa dipecah menjadi Aliran Kelembagaan Lama, Aliran Quasi Kelembagaan, dan aliran Kelembagaan Baru, bukan berarti satu aliran lebih baik dibandingkan aliran yang lain. Hal ini membawa implikasi terdapatnya kebebasan untuk mengikuti salah satu aliran, sesuai dengan kepercayaan akan ketepatan dan kemanfaatan pemakaian salah satu aliran Kelembagaan.

Penganekaragaman pendidikan ekonomi yang selama ini didominasi oleh aliran ortodoks sangatlah penting, salah satunya adalah dengan lebih mengenal dan memperdalam akan adanya aliran ekonomi Kelembagaan. Bahkan, dalam penelitian lebih digandakan lagi penggunaannya, mengingat masalah ekonomi di Indonesia begitu rumit, kompleks, dan menantang.

\section{DAFTAR PUSTAKA}

Arif, Sritua, (2006). Negeri Terjajah Menyingkap Ilusi Kemerdekaan. Yogyakarta: Resist Book.

Arifin, Bustanul, dan Didik J. Rachbani. (2001). Ekonomi Politik dan Kebijakan Publik. Jakarta: Grasindo.
Arifin, Bustanul. (2005). Ekonomi Kelembagaan Pangan. Jakarta: LP3ES.

Brue, Stanley L. (2000). The Evolution of Economic Thought. USA: The Dryden Press.

Chariri, Anis, (2006). The Dynamics of Financial Reporting Practice in an Indonesian Insurance Company: a Reflection of Javanese Views on an Ethical Sosial Relationship. School of Accounting and Finance, University of Wollongong. Disertasi tidak Diterbitkan.

Hasibuan, Nurimansjah, (2003). Sejarah Pemikiran Ekonomi. Jakarta: Pusat Penerbitan Universitas Terbuka.

Jaya, Wihana Kirana, (2004). New Institutional Economics of the State; an Alternative Approach to Regional Autonomy in Indonesia. Jurnal Ekonomi dan Bisnis Indonesia, Vol 19, No.4, 327-339.

Karseno, Arief Ramelan dan Ari Adjie. (2001). Kebijakan Ekonomi dan Pembangunan Kelembagaan di Indonesia. Yogyakarta: UPP AMP YPKN.

Keen, Steve, (2001). Debunking Economics the Naked Emperor of the Social Sciences. New York: Pluto Press-Zed Books.

Landreth, Harry, and David C. Colander. (1994). History of Economic Thought. USA: Hughton Miffin Company.

Mubyarto, (2002). Meninjau Kembali Ekonomika Neoklasik. Jurnal Ekonomi dan Bisnis Indonesia, Vol 17, No.2, 119129.

Mubyarto, (2002). Peran Ilmu Ekonomi dalam Pemberdayaan Ekonomi Rakyat, 
Jurnal Ekonomi dan Bisnis Indonesia, Vol 17, No.3, 233-242.

Myrdal, Gunnar, (1969). The Political Element in the Development of Economic Theory. New York: Simon and Schuster.

Myrdal, Gunnar, (1972). Asian Drama. An Inquiry in to the Poverty of Nations. An Abridgment by Seth S. King. New York: Vintage Books.

Omerod, Paul. (1998). Matinya Ilmu Ekonomi. Terjemahan Parakitri T. Simbolon. Jakarta: Gramedia.

Perkins, John, (2005). Confessions of an Economic Hitman. Pengakuan Seorang Ekonom Perusak. Terjemahan. Herman Tirtaatmadja dan Dwi Karyani. Jakarta: Abdi Tandur.

Santosa, Purbayu Budi, (1985). Peranan Gotong Royong pada Pembangunan Desa (Studi Kasus Desa Karanganyar). Skripsi. Fakultas Ekonomi Universitas Diponegoro. Tidak Diterbitkan.

Santosa, Purbayu Budi, (2006). Gangguan Politik Uang terhadap Pembangunan" dalam Jurnal Dinamika Ekonomi \& Bisnis. Vol.3., No. 1, Maret 2006.
Stiglittz, Joseph E., (2002). Globalization and its Discontents. New York: WW Norton.

Sugiyanto, FX, (2007). Metode Berpikir Ekonomi Mainstream, Etika dan Keadilan. Pidato Pengukuhan disampaikan pada Upacara Penerimaan Jabatan Guru Besar dalam Ilmu Ekonomi pada Fakultas Ekonomi Universitas Diponegoro pada tanggal 7 Juli 2007. Semarang: Badan Penerbit Undip

Swasono, Sri-Edi, (2002). Tantangan Perekonomian Indonesia Masa Depan: Kompetensi dan Integritas Sarjana Ekonomi Kita. Ceramah di depan Alumni Fakultas Ekonomi Universitas Diponegoro, Semarang, 19 Oktober 2002.

Yustika, Ahmad Erani, (2005). Problems of the Indonesian Sugar Industry: an Institutional Economics Perspective, Jurnal Ekonomi dan Bisnis Indonesia. Vol.20, No.4, 368-382.

Yustika, Ahmad Erani, (2006). Ekonomi Kelembagaan Definisi, Teori, dan Strategi. Malang: Bayu Media. 